\title{
Association of increased phagocytic NADPH oxidase- dependent superoxide production with diminished nitric oxide generation in essential hypertension Ana Fortuño ${ }^{a}$, Sara Oliván ${ }^{\mathrm{a}}$, Oscar Beloqui ${ }^{\mathrm{b}}$, Gorka San Joséa ${ }^{\mathrm{a}}$, María U. Moreno ${ }^{\mathrm{a}}$, Javier Díez ${ }^{\mathrm{a}, \mathrm{c}}$ and Guillermo Zalba ${ }^{\mathrm{a}}$
}

\begin{abstract}
Objective Oxidative stress has been implicated in the pathogenesis of hypertension and its complications through alterations in nitric oxide (NO) metabolism. This study was designed to investigate whether a relationship exists between phagocytic nicotinamide adenine dinucleotide phosphate (NADPH) oxidase-dependent superoxide anion $\left(\bullet_{2}{ }^{-}\right)$production and NO generation in patients with essential hypertension.
\end{abstract}

Methods Superoxide production was assayed by chemiluminescence under baseline and stimulated conditions on mononuclear cells obtained from hypertensives $(n=51)$ and normotensives $(n=43)$. NO production was evaluated by determining serum $\mathrm{NO}$ metabolites, nitrate plus nitrite (NOx).

Results Although there were no differences in baseline $-\mathrm{O}_{2}-$ production between normotensives and hypertensives, the $\cdot \mathrm{O}_{2}{ }^{-}$production in phorbol myristate acetate (PMA)-stimulated mononuclear cells was increased $(P<0.05)$ in hypertensives compared with normotensives. The PMA-induced $\cdot \mathrm{O}_{2}{ }^{-}$production was completely abolished by apocynin, a specific inhibitor of NADPH oxidase. Moreover, stimulation of $\bullet^{-}{ }_{2}{ }^{-}$production by angiotensin II and endothelin-1 was higher $(P<0.05)$ in cells from hypertensives than in cells from normotensives. In addition, diminished $(P<0.001)$ serum NOx was detected in hypertensives compared with normotensives. Interestingly, an inverse correlation $(r=0.493, P<0.01)$ was found between $\cdot \mathrm{O}_{2}{ }^{-}$production and $\mathrm{NOx}$ in hypertensives.

Conclusions Generation of $\bullet_{2}{ }^{-}$mainly dependent on NADPH oxidase is abnormally enhanced in stimulated mononuclear cells from hypertensives. It is suggested that this alteration could be involved in the diminished NO production observed in these patients. $J$ Hypertens 22:2169-2175 @ 2004 Lippincott Williams \& Wilkins.

Journal of Hypertension 2004, 22:2169-2175

Keywords: hypertension, mononuclear cells, NADPH oxidase, nitric oxide

${ }^{a}$ Area of Cardiovascular Pathophysiology, Center for Applied Medical Research, ${ }^{b}$ Department of Internal Medicine, University Clinic and ${ }^{\mathrm{C}}$ Department of Cardiology and Cardiovascular Surgery, University Clinic, School of Medicine, University of Navarra, Pamplona, Spain.

Sponsorship: This work was supported by a grant from the UTE project FIMA, the Departamento de Salud del Gobierno de Navarra (55/2002) and by the Fundación de Aguas de Valencia, Spain

Correspondence and requests for reprints to Ana Fortuño, $\mathrm{PhD}$, Area of Cardiovascular Pathophysiology, School of Medicine, C/Irunlarrea 1, 31008 Pamplona, Spain.

Tel: + 34948 425600; fax: + 34948 425652; e-mail: afortuno@unav.es

Received 20 February 2004 Revised 3 June 2004 Accepted 22 June 2004

\section{Introduction}

A number of findings support the notion that superoxide anion $\left(\bullet \mathrm{O}_{2}^{-}\right)$plays an important role in the pathophysiology of cardiovascular diseases, including essential hypertension [1]. An enhanced generation of - $\mathrm{O}_{2}{ }^{-}$may cause a loss of nitric oxide (NO) production, which leads, among other consequences, to endothelial dysfunction [2]. The nicotinamide adenine dinucleotide phosphate $(\mathrm{NAD}(\mathrm{P}) \mathrm{H})$ oxidase system is considered to be the most important source of $\bullet \mathrm{O}_{2}{ }^{-}$in vascular cells $[3,4]$. Several studies have demonstrated the involvement of vascular $\mathrm{NAD}(\mathrm{P}) \mathrm{H}$ oxidase in experimental and clinical hypertension. In rats made hypertensive by chronic angiotensin (Ang) II infusion, vascular $\mathrm{NAD}(\mathrm{P}) \mathrm{H}$ oxidase-dependent $\bullet \mathrm{O}_{2}{ }^{-}$production is dramatically increased [5]. On the other hand, the enhanced $\bullet \mathrm{O}_{2}{ }^{-}$production present in the aorta of spontaneously hypertensive rats (SHR) and deoxycorticosterone acetate-salt hypertensive rats is associated with increased $\mathrm{NAD}(\mathrm{P}) \mathrm{H}$ oxidase activity [6,7]. Recently, increased $\mathrm{NAD}(\mathrm{P}) \mathrm{H}$ oxidase-dependent $\bullet \mathrm{O}_{2}{ }^{-}$ production has been described in smooth muscle cells from resistance arteries of hypertensives [8].

NADPH oxidase is also the major inducible source of $-\mathrm{O}_{2}{ }^{-}$in phagocytic cells, including lymphocytes, monocytes and neutrophils $[9,10]$. Although increased $\bullet \mathrm{O}_{2}{ }^{-}$ production in neutrophils from hypertensives has been found by several authors [11-13], no changes in this parameter were reported by others [14,15]. In addition, the enzymatic source of $\bullet \mathrm{O}_{2}{ }^{-}$was not clearly demonstrated in these studies. Besides, other phagocytic cells 
may also be involved in the pathophysiology of hypertension. An association of endothelial dysfunction with subendothelial monocyte/macrophage infiltration has been reported in SHR [16]. In addition, recent data suggest that infiltration of the kidney by lymphocytes and monocytes/macrophages play a role in the development of hypertension in SHR through mechanisms involving enhanced $\bullet \mathrm{O}_{2}{ }^{-}$production [17]. Moreover, available clinical data indicate that peripheral monocytes/macrophages and lymphocytes are activated in hypertensives compared with normotensives [18]. Therefore, we have hypothesized that an association may exist between $\bullet \mathrm{O}_{2}{ }^{-}$overproduction by monocytes and lymphocytes and diminished NO production in patients with essential hypertension. To test this hypothesis NADPH oxidase-dependent $\bullet \mathrm{O}_{2}{ }^{-}$production in peripheral mononuclear cells, monocytes and lymphocytes, as well as the serum concentration of $\mathrm{NO}$ metabolites (NOx), an index of systemic NO generation, were evaluated in hypertensives and normotensives.

\section{Methods}

The study population consisted of two groups of subjects who attended for routine medical examination at the University Clinic of Navarra. The hypertensive group consisted of 51 patients with repeatedly documented elevated systolic blood pressure $(\mathrm{SBP})>$ $139 \mathrm{mmHg}$ and/or diastolic blood pressure (DBP) $>$ $89 \mathrm{mmHg}$. Antihypertensive medication was reported by 22 patients $(43 \%)$ as monotherapy or in combination. The normotensive group consisted of 43 apparently healthy subjects. All patients had appropriate clinical and laboratory evaluations to exclude hypertension secondary to other disorders [19]. Blood samples were collected after an overnight (12-14 h) fast, and plasma glucose, serum total, low-density lipoprotein (LDL) and high-density lipoprotein (HDL) cholesterol, triglyceride and C-reactive protein were determined by standard laboratory protocols. All subjects gave written informed consent to participate in the study, and the Institutional Review Committee of the University Clinic approved the protocol. The study conformed to the principles of the Helsinki Declaration.

\section{Preparation of phagocytic cells}

Phagocytic cells were isolated from blood samples obtained by a Ficoll-Hypaque gradient. Briefly, blood samples $(15 \mathrm{ml})$ obtained from each subject in ethylenediaminetetra-acetic acid (EDTA) $\mathrm{K}_{3}$ tubes were diluted with physiological serum $(1: 1)$ and the mixture was layered on $15 \mathrm{ml}$ of Lymphoprep ${ }^{\mathrm{TM}}$ (Axis-Shield PoC AS, Oslo, Norway) and then centrifuged for $20 \mathrm{~min}$ at room temperature and $1000 \mathrm{~g}$. The interface of phagocytic cells was carefully aspirated and washed twice in physiological serum through centrifugation for $10 \mathrm{~min}$ at room temperature and $300 \mathrm{~g}$. The pellet was then resuspended in PBS (Gibco BRL, Paisley, Scotland, UK) ready for use. Mononuclear cells were counted in a Neubauer chamber. To obtain reproducible data soft agitation at $37^{\circ} \mathrm{C}$ of the final cell suspension was necessary to avoid cell aggregation. On the other hand, this agitation was soft enough to avoid endogenous stimulation.

\section{Measurement of $\cdot \mathrm{O}_{2}-$ production in intact cells}

Luminescence assays with lucigenin $(10 \mu \mathrm{mol} / \mathrm{l}$; Sigma, St Louis, Missouri, USA) as the electron acceptor were used to measure $\bullet_{2}{ }^{-}$production in $4 \times 10^{5}$ mononuclear cells that were incubated at $37^{\circ} \mathrm{C}$ for $30 \mathrm{~min}$ alone or in presence of stimulus or inhibitors. The reaction was started by the addition of lucigenin to cell samples. Luminescence was measured every $11 \mathrm{~s}$ for $5 \mathrm{~min}$ in a tube luminometer (Berthold Detection System, Sirius, Pforzheim, Germany). A buffer blank was subtracted from each reading. The determinations were performed under baseline conditions and also after maximum stimulation by the protein kinase $\mathrm{C}$ (PKC) activator, phorbol myristate acetate (PMA, $2 \mathrm{mg} /$ 1, Sigma) at $37^{\circ} \mathrm{C}$. A kinetic study of baseline and stimulated mononuclear cells response was carried out and the value of the area under the curve was used to quantify chemiluminescence. Data are expressed as relative light units produced per second. In some experiments, the effect of diphenylene iodonium (DPI, $5 \mu \mathrm{mol} / \mathrm{l}$; Sigma), a flavoprotein inhibitor, and apocynin $\left(2.5 \times 10^{-3} \mathrm{~mol} / \mathrm{l}\right.$; Calbiochem, Darmstadt, Germany), a specific intracellular inhibitor of NADPH oxidase assembly, were studied $[20,21]$. To verify the specificity of the lucigenin assay for $\bullet \mathrm{O}_{2}{ }^{-}$production, the effect of superoxide dismutase (SOD, $10000 \mathrm{U} / \mathrm{ml}$, Sigma), an enzymatic scavenger of $\bullet \mathrm{O}_{2}^{-}$, was examined.

Although lucigenin concentration was low enough to avoid autoxidation, the measurements were validated against an independent measurement of $\bullet \mathrm{O}_{2}{ }^{-}$production using SOD-inhibitable ferrycytochrome $c$ reduction. Mononuclear cells $\left(4 \times 10^{5}\right)$ were incubated in $500 \mu \mathrm{l}$ of buffer containing ferrycytochrome $C$ (80 $\mu \mathrm{mol} / \mathrm{l}$; Sigma) at $37^{\circ} \mathrm{C}$ for $60 \mathrm{~min}$ in the presence or absence of SOD (10000 U/ml, Sigma) and finally the absorbance was measured at $550 \mathrm{~nm}$. The PMA-stimulated production measured by lucigenin-enhanced chemiluminescence was closely related with measurements determined in parallel by ferricytochrome $c$ reduction.

In some experiments $\bullet \mathrm{O}_{2}{ }^{-}$production in mononuclear cells was analysed in response to physiological agonist, such as Ang II $(0.1 \mu \mathrm{mol} / \mathrm{l} ;$ Sigma $)$ and endothelin (ET)-1 $(0.01 \mu \mathrm{mol} / \mathrm{l}$, Sigma). Furthermore, the upstream signalling pathways involved in NADPH oxidase-mediated $\bullet \mathrm{O}_{2}{ }^{-}$production were also investigated with specific inhibitors of PKC (bisindolinmalenide 
(BIS) I, $10 \mu \mathrm{mol} / \mathrm{l}$, Calbiochem), phosphatidylinositol3-kinase (wortmannin, $1 \mu \mathrm{mol} / \mathrm{l}$, Sigma), MEK (PD 98059, 50 mol/l; Calbiochem), p38 MAPK (SB 203580, $1 \mu \mathrm{mol} / \mathrm{l}$, Sigma) and tyrosine kinase (tyrphostin, $1 \mu \mathrm{mol} / \mathrm{l}$, Sigma).

\section{Determination of serum NOx}

Serum samples collected after an overnight (12-14 h) fast were prepared after centrifugation blood samples. Nitrate and nitrite $\left(\mathrm{NO}_{2}{ }^{-} / \mathrm{NO}_{3}{ }^{-}\right)$are stable $\mathrm{NO}$ metabolites and their serum concentration reflects systemic NO production [22]. After serum ultrafiltration, by means of centrifugation at $14000 \mathrm{~g}$ for $20 \mathrm{~min}$ and filters with a cut-off of $30 \mathrm{kDa}, \mathrm{NOx}$ concentration was evaluated directly from the supernatant using a colorimetric assay based on Griess reaction (Cayman Chemical Company, Ann Arbor, Michigan, USA). The absorbance of the samples was determined at 540-nm wavelength and compared with those of known concentrations of sodium nitrite.

\section{Statistical analysis}

Data are reported as means \pm standard error (SEM). Statistical differences between mean values were tested by Student's $t$ test for unpaired data once normality was demonstrated (Shapiro-Wilk test); otherwise a Mann-Whitney U test was used. When more than two groups were analysed Kruskal-Wallis followed by a Mann-Whitney U test was employed. Correlation between continuously distributed variables was analysed by calculation of the linear regression and correlation coefficients. The significant level for all tests was taken as $P<0.05$.

\section{Results}

The clinical characteristics of the studied subjects are summarized in Table 1. Hypertensives were older than

Table 1 Clinical, demographic and biochemical characteristics of normotensive subjects and hypertensive patients

\begin{tabular}{lccc}
\hline & Normotensives & Hypertensives & $P$ \\
\hline Age (years) & $54.5 \pm 1.9$ & $61.2 \pm 1.3$ & 0.016 \\
Gender (M/F) & $29 / 14$ & $38 / 13$ & 0.445 \\
BMl (kg/m ${ }^{2}$ ) & $28.5 \pm 0.4$ & $29.8 \pm 0.6$ & 0.213 \\
Smoking (yes/no) & $17 / 26$ & $15 / 36$ & 0.164 \\
Diabetes mellitus (yes/no) & $10 / 33$ & $15 / 36$ & 0.180 \\
Hypercholesterolemia (yes/no) & $22 / 21$ & $26 / 25$ & 0.777 \\
SBP (mmHg) & $122.1 \pm 2.1$ & $150.1 \pm 1.9$ & 0.000 \\
DBP (mmHg) & $78.9 \pm 1.3$ & $91.5 \pm 1.2$ & 0.000 \\
MAP (mmHg) & $94.2 \pm 1.2$ & $110.5 \pm 1.0$ & 0.000 \\
PP (mmHg) & $45.1 \pm 1.4$ & $59.5 \pm 2.0$ & 0.000 \\
C-reactive protein (mg/dl) & $0.29 \pm 0.03$ & $0.32 \pm 0.02$ & 0.635 \\
Glucose (mg/dl) & $98 \pm 2$ & $103 \pm 2$ & 0.075 \\
Total cholesterol (mg/dl) & $229 \pm 6$ & $234 \pm 5$ & 0.680 \\
HDL-cholesterol (mg/dl) & $47 \pm 2$ & $51 \pm 2$ & 0.110 \\
LDL-cholesterol (mg/dl) & $158 \pm 5$ & $161 \pm 4$ & 0.885 \\
Triglyceride (mg/dl) & $111 \pm 8$ & $112 \pm 7$ & 0.775 \\
\hline
\end{tabular}

Values are mean \pm SEM or number of subjects. BMI, body mass index; SBP, systolic blood pressure; DBP, diastolic blood pressure; MAP, mean arterial pressure; PP, pulse pressure; HDL, high-density lipoproteins; LDL, low-density lipoproteins. normotensives. No differences were found between normotensives and hypertensives with regard to gender, frequency of smoking, body mass index and prevalence of diabetes mellitus or hypercholesterolemia. The values of blood pressure were higher in the hypertensives than in the normotensives. As expected, and since the antihypertensive treatment was ineffective in treated patients, no differences were found in blood pressure values between treated and untreated hypertensive patients.

Preliminary experiments showed that PMA $(2 \mathrm{mg} / \mathrm{l})$ achieved the maximum $\bullet \mathrm{O}_{2}{ }^{-}$production after $10 \mathrm{~min}$ of incubation. Concentration and time of incubation was determined after dose- and time-response curves had been constructed (data not shown). The PMAstimulated $\bullet \mathrm{O}_{2}{ }^{-}$production was inhibited by DPI $(5 \mu \mathrm{mol} / \mathrm{l})$ and apocynin $\left(2.5 \times 10^{-3} \mathrm{~mol} / \mathrm{l}\right)$. SOD $(10000$ $\mathrm{U} / \mathrm{ml}$ ) also abolished the cellular-induced increase in chemiluminescence PMA-stimulated conditions (Fig. 1). No differences with basal levels of chemiluminescence derived from unstimulated cells were observed. Thus, these results suggest that the enzymatic complex of NADPH oxidase may be the enzymatic source of $-\mathrm{O}_{2}{ }^{-}$from mononuclear cells in the conditions of the present study.

Fig. 1

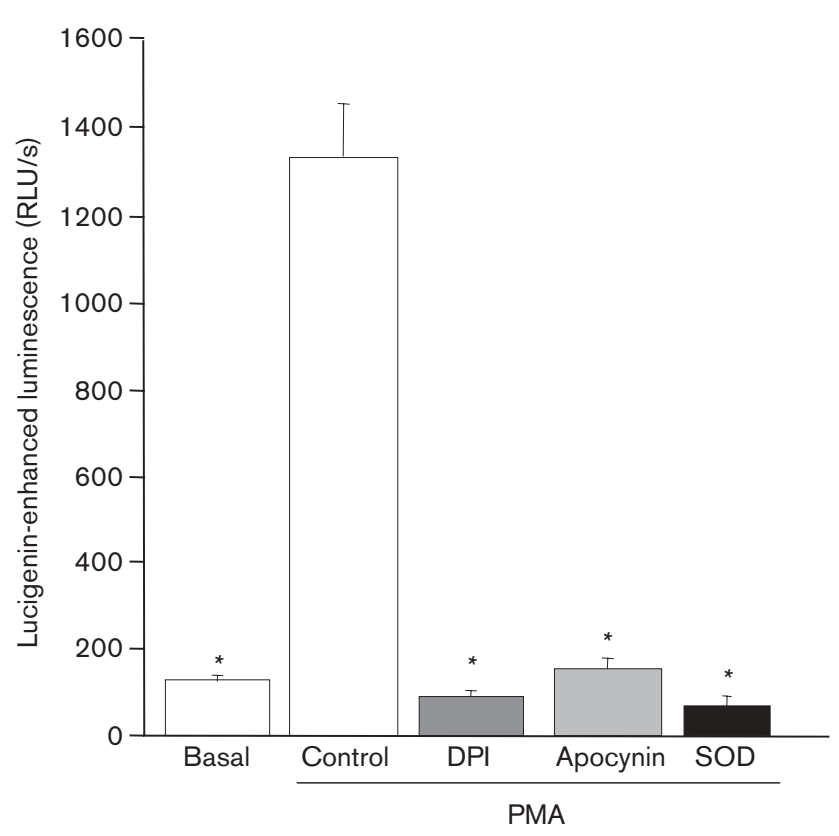

Effects of diphenylene iodonium (DPI; $5 \mu \mathrm{mol} / \mathrm{l})$, apocynin $\left(2.5 \times 10^{-3}\right.$ $\mathrm{mol} / \mathrm{l}$ ) and superoxide dismutase (SOD; $10000 \mathrm{U} / \mathrm{ml}$ ) on phorbol myristate acetate (PMA)-stimulated $\bullet \mathrm{O}_{2}^{-}$generation assayed in control conditions. Mononuclear cells were stimulated for 10 min with PMA $(2 \mathrm{mg} / \mathrm{l})$ before lucigenin $(10 \mu \mathrm{mol} / \mathrm{l})$ was added. Data are expressed as mean + standard error (SE). RLU/s, relative light units per second. ${ }^{\star} P<0.01$ versus control. 
The values of baseline and PMA-stimulated $\bullet \mathrm{O}_{2}{ }^{-}$ production in mononuclear cells from hypertensives and normotensives are shown in Figure 2. The mean levels of $\bullet \mathrm{O}_{2}{ }^{-}$production from non-stimulated mononuclear cells were similar in the two groups of subjects. The addition of PMA stimulated $\bullet \mathrm{O}_{2}{ }^{-}$production both in normotensives $(134.9 \pm 18.9$ versus $1320.7 \pm 148.1$ relative light units (RLU)/s; $P<0.001$ ) and hypertensives $(131.7 \pm 16.5$ versus $1748.7 \pm 147.4 \mathrm{RLU} / \mathrm{s}$; $P<0.001)$. The magnitude of this stimulation was higher $(P<0.05)$ in cells from hypertensives than in cells from normotensives. Since hypertensives were older than normotensives, and in order to discard an effect of age on PMA-stimulated $\bullet \mathrm{O}_{2}{ }^{-}$production, this parameter was evaluated across quartiles of age, in the whole population and in the hypertensive group and no significant tendency was found. On the other hand, there were no differences in the values of PMAstimulated NADPH oxidase-dependent $\bullet \mathrm{O}_{2}{ }^{-}$production between treated and untreated $(n=22,1562 \pm 196$ $\mathrm{RLU} / \mathrm{s}$ versus $n=29,1910 \pm 215 \mathrm{RLU} / \mathrm{s}$, respectively, $P=0.261$ ) hypertensives. As the study was not randomized, nothing about the prophylaxis of the antihypertensive therapy (doses, time of treatment.) was controlled. Interestingly, we possessed information concerning the ability of the antihypertensive agents to interfere with the renin-angiotensin system. No differ-

Fig. 2

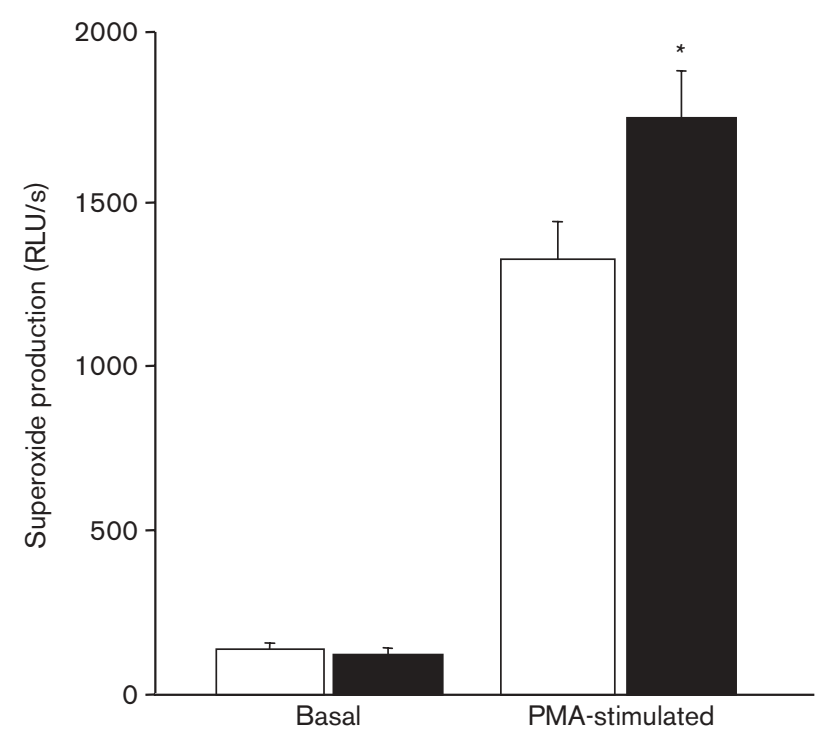

Baseline and phorbol myristate acetate (PMA)-stimulated $\bullet \mathrm{O}_{2}{ }^{-}$ generation in mononuclear cells obtained from normotensives (open bars) and hypertensives (closed bars). Intact mononuclear cells were incubated for $10 \mathrm{~min}$ with PMA $(2 \mathrm{mg} / \mathrm{l})$ and the rate of $\bullet \mathrm{O}_{2}$

production was evaluated by lucigenin $(10 \mu \mathrm{mol} / \mathrm{l})$ chemiluminescence. Data are expressed as mean + standard error (SE). RLU/s, relative light units per second. ${ }^{\star} P<0.05$ versus normotensive controls. ences were found in PMA-stimulated $\bullet \mathrm{O}_{2}{ }^{-}$production depending on the antihypertensive therapy.

Finally, and in order to check if the mononuclear cells from hypertensives showed a higher response than normotensives to physiological agonist, we evaluated the $\bullet \mathrm{O}_{2}{ }^{-}$production induced by Ang II $(0.1 \mu \mathrm{mol} / \mathrm{l})$ and ET-1 $(0.01 \mu \mathrm{mol} / \mathrm{l}) \cdot \bullet \mathrm{O}_{2}^{-}$production was significantly higher in hypertensives than in normotensives in response to both Ang II $(226.8 \pm 7.9$ versus $130.1 \pm$ 14.9 RLU/s; $P<0.05)$ and ET-1 $(211.4 \pm 6.1$ versus $133.8 \pm 15.1 \mathrm{RLU} / \mathrm{s} ; P<0.05)$ (Fig. 3).

Furthermore, we investigated the upstream signalling pathways involved in the PMA-stimulated $\bullet \mathrm{O}_{2}{ }^{-}$production in a subgroup of individuals. BIS I $(10 \mu \mathrm{mol} / \mathrm{l})$, a protein kinase $\mathrm{C}$ (PKC) inhibitor, completely inhibited $\bullet \mathrm{O}_{2}{ }^{-}$production. Wortmannin $1 \mu \mathrm{mol} / \mathrm{l}$, inhibited - $\mathrm{O}_{2}{ }^{-}$production by $80 \%$ and both, PD $9805950 \mu \mathrm{mol} / \mathrm{l}$ and SB $2035801 \mu \mathrm{mol} / \mathrm{l}$ inhibited by $70 \%$ the effect measured in the present study. Finally, tyrphostin $1 \mu \mathrm{mol} / \mathrm{l}$ inhibited by $50 \%$. No differences were found in the effect of the tested inhibitors on $\bullet \mathrm{O}_{2}{ }^{-}$production between normotensives $(n=10)$ and hypertensives $(n=10)$.

The NOx levels were lower $(P<0.001)$ in hypertensives than in normotensives (Fig. 4). Again, there were no differences in the values of $\mathrm{NOx}$ between

Fig. 3

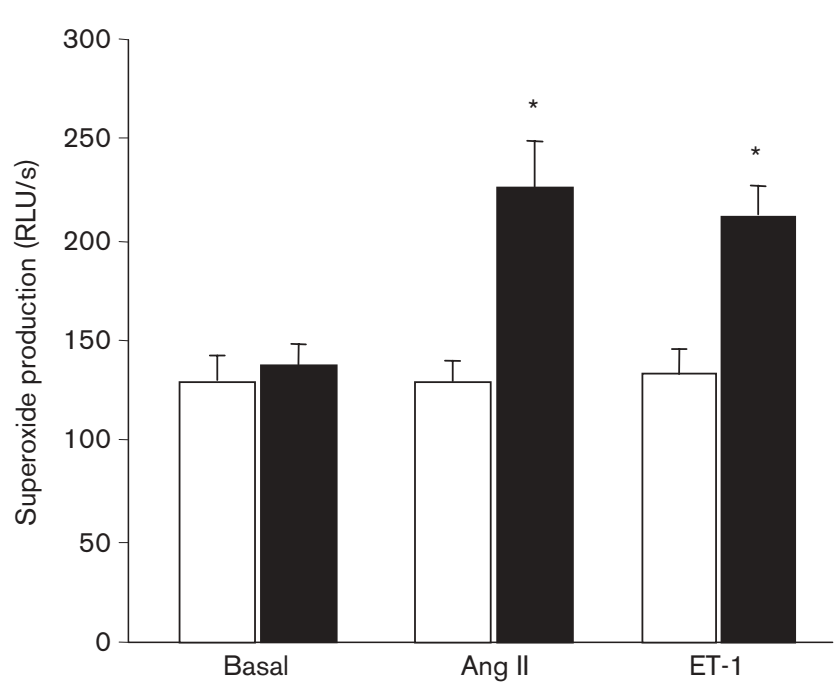

Baseline and angiotensin (Ang) II $(0.1 \mu \mathrm{mol} / \mathrm{l})$ and endothelin (ET) - 1 $(0.01 \mu \mathrm{mol} / \mathrm{l})$-stimulated $\bullet \mathrm{O}_{2}{ }^{-}$generation in mononuclear cells obtained from normotensives (open bars, $n=10$ ) and hypertensives (closed bars, $n=10$ ). The rate of $\bullet \mathrm{O}_{2}^{-}$production was evaluated by lucigenin $(10 \mu \mathrm{mol} / \mathrm{l})$ chemiluminescence. Data are expressed as mean + standard error (SE). RLU/s, relative light units per second. ${ }^{\star} P<0.05$ versus normotensive controls. 
Fig. 4

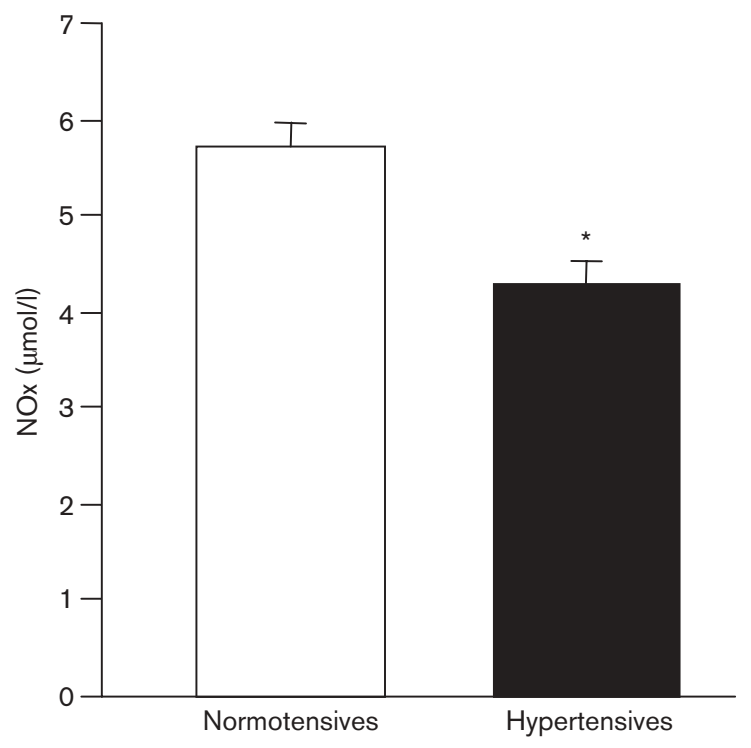

Serum levels of nitric oxide metabolites (NOx) in normotensive subjects and hypertensive patients. Data are expressed as mean + standard error (SE). ${ }^{\star} P<0.001$ versus normotensive controls.

treated and untreated hypertensives $(4.5 \pm 0.2 \mu \mathrm{mol} / \mathrm{l}$ versus $4.3 \pm 0.2 \mu \mathrm{mol} / \mathrm{l}$, respectively, $P=0.261)$. An inverse correlation was found between NOx concentration and PMA-stimulated $\bullet \mathrm{O}_{2}{ }^{-}$generation in the hypertensive population (Fig. 5).

\section{Discussion}

The major finding of this study is that NADPH oxidase-dependent $\bullet \mathrm{O}_{2}{ }^{-}$production is abnormally enhanced in mononuclear cells from hypertensive patients. The NADPH oxidase is a multicomponent enzyme that has a membrane portion collectively known as cytochrome $b_{558}$, that is inactive until it is associated with the cytosolic components (see $[9,10]$ for review). Apocynin is a potent intracellular inhibitor of the assembly of the NADPH oxidase upon stimulation, since it impedes the assembly of the $\mathrm{p} 47^{\text {phox }}$ and p67 $7^{\text {phox }}$ subunits within the membrane NADPH oxidase complex $[20,21]$. This agent has no known inhibitory effects upon the other potential sources of reactive oxygen species [20]. Thus, our findings showing complete inhibition of PMA-stimulated $\bullet \mathrm{O}_{2}{ }^{-}$production observed in the presence of apocynin strongly suggests that the enzymatic complex of NADPH oxidase is the source of $\bullet \mathrm{O}_{2}^{-}$.

The exaggerated response to PMA of hypertensive cells might be the result of a state of preactivation. In fact, preactivated monocytes exhibit increased adher-
Fig. 5

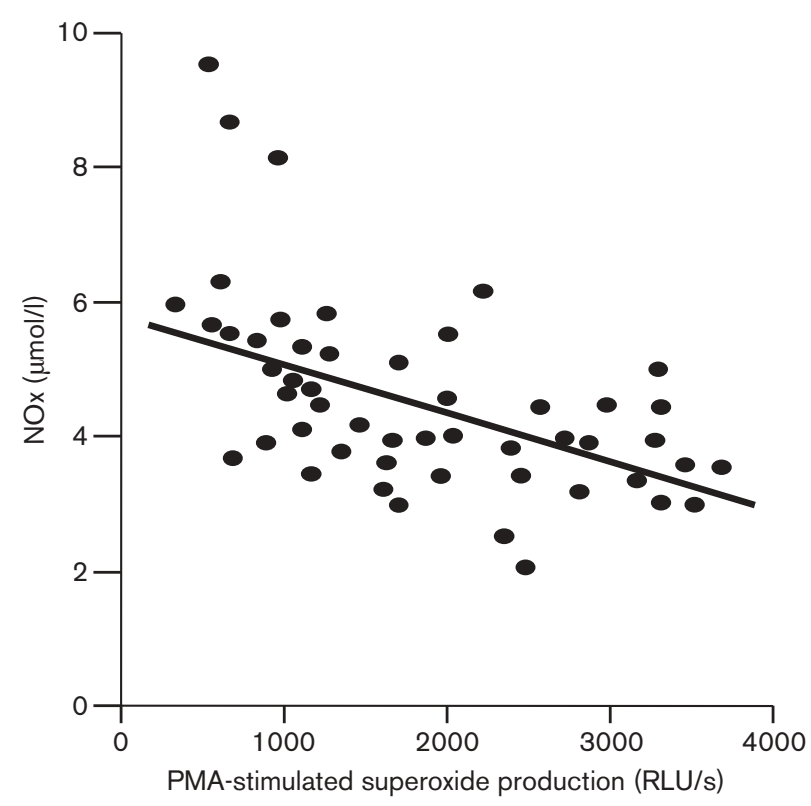

Inverse correlation between phorbol myristate acetate (PMA)stimulated $\bullet \mathrm{O}_{2}{ }^{-}$production and nitric oxide metabolites (NOx) in hypertensive patients; $y=6.61-0.00067 x ; r=0.493, P<0.01$. RLU/ $\mathrm{s}$, relative light units per second.

ence to endothelial cells and increased release of cytokines upon stimulation in hypertensives [23-25]. Several potential stimulating factors of the $\operatorname{NAD}(\mathrm{P}) \mathrm{H}$ oxidase enzymatic system deserve to be considered in the setting of arterial hypertension. The role of humoral factors in the upregulation of $\mathrm{NAD}(\mathrm{P}) \mathrm{H}$ oxidase activity has been extensively documented [26]. Ang II- and ET-1-enhanced NAD $(\mathrm{P}) \mathrm{H}$ oxidase activity has been described in several kinds of cells, including smooth muscle cells [27,28] and monocytes [23,29]. Our findings showing a higher $\bullet \mathrm{O}_{2}{ }^{-}$production in response to Ang II and ET-1 in hypertensives than in normotensives support a potential role of these factors in the activation of mononuclear cells on the hypertensive state. In addition, Ungvari et al. [30] have recently demonstrated that mechanical stress associated with high pressure induces $\bullet \mathrm{O}_{2}^{-}$production in isolated arteries via stimulation of NADPH oxidase. The question as to whether mechanical forces may also play a role on phagocytic enzymatic system merits investigation. Nevertheless, our finding that PMA-stimulated - $\mathrm{O}_{2}{ }^{-}$production is increased in those treated hypertensives in whom blood pressure remains raised suggest that mechanical forces may play an important regulatory role in the activation of phagocytic NADPH oxidase. Additionally, previous works support that a genetic background may also contribute to the activation of NAD(P)H oxidase [31-33]. 
Underlying mechanisms for this increased $\bullet \mathrm{O}_{2}{ }^{-}$production are unclear, although data from several studies suggest a potential role for p38 and ERK MAPKs, tyrosin kinases and PKC [34-36]. Data here presented support the involvement of all these pathways in the regulation of NADPH oxidase-mediated $\bullet \mathrm{O}_{2}{ }^{-}$production in phagocytes. Moreover, PMA is thought to stimulate NADPH oxidase to produce $\bullet \mathrm{O}_{2}{ }^{-}$by activation of PKC. In accordance with this view, increased PMA-stimulated $\bullet \mathrm{O}_{2}{ }^{-}$production was blocked by BIS, an inhibitor of PKC. The potential relevance of these data is remarked by a number of findings showing that hemodynamic and humoral factors, including Ang II and ET-1, activate NADPH oxidase through PKCdependent mechanisms $[30,37,38]$.

A second finding of this study is that the serum nitrate plus nitrite concentration was lower in hypertensives than in normotensives. This finding confirms previous data reported by others in the hypertensive population $[39,40]$. NO is rapidly oxidized to nitrite and then to nitrate by oxygenated hemoglobin, molecular oxygen and $\bullet \mathrm{O}_{2}{ }^{-}$, so the major oxidative metabolites are nitrite and nitrate. Although $\mathrm{NO}$ is able to react with $\bullet \mathrm{O}_{2}{ }^{-}$to form peroxynitrate, this compound may lead to nitration of tyrosine or may isomerase to nitrates [41]. Nevertheless, serum nitrotyrosine levels were undetectable in our population (data not shown). Thus, NOx measurements obtained in this study clearly reflect real changes in NO generation. Impaired expression/activity of endothelial NO synthase (eNOS) could cause the diminished production of $\mathrm{NO}$ observed in hypertensives (Reviewed in [42]). In addition, eNOS-mediated NO production may be reduced when the enzyme is deprived of its critical cofactor tetrahydrobiopterin or its substrate L-arginine [43]. This phenomenon has been referred to as eNOS uncoupling. Oxidation of tetrahydrobiopterin by peroxynitrite may also lead to uncoupling of eNOS [44]. Landmesser et al. [45] have recently demonstrated that $\mathrm{NAD}(\mathrm{P}) \mathrm{H}$ oxidase is critically important in producing reactive oxygen species that ultimately oxidize tetrahydrobiopterin in blood vessels of hypertensive animals. Our finding of an inverse correlation between NADPH oxidase-dependent $\bullet \mathrm{O}_{2}{ }^{-}$production and $\mathrm{NO}$ metabolites in hypertensives supports this possibility. In agreement with this, blockage of the $\beta$-receptors inhibits the phagocytic NADPH oxidase activity and prevents eNOS uncoupling in experimental hyperlipidemia [46].

The potential role of phagocytic NADPH oxidase in the pathogenesis of hypertension is unclear. Several groups have demonstrated an increased $\bullet \mathrm{O}_{2}{ }^{-}$generation in neutrophils from hypertensives [11-13]. It has also been reported that ROS production is increased in immortalized lymphocytes from hypertensives [47]. Augmented infiltration of monocytes and lymphocytes in the vascular wall of SHR, associated with enhanced - $\mathrm{O}_{2}{ }^{-}$production that impair, among others, the endothelial function have been demonstrated [16,17]. Thus, the findings here reported showing a higher NADPH oxidase-dependent $\bullet \mathrm{O}_{2}{ }^{-}$production in stimulated mononuclear cells from hypertensives suggest that infiltrated mononuclear cells may play a relevant role in the development of oxidative stress in the vascular wall, favouring endothelial dysfunction, among other mechanisms, by an impaired NO production. Further studies are required to demonstrate the molecular evidence linking an increased $\bullet \mathrm{O}_{2}{ }^{-}$generation with a diminished NO production.

Some limitations of the present study should be acknowledged. First, half of the patients were under antihypertensive treatment but it was inadequate in terms of blood pressure control and apparently it did not influence $\bullet^{-}{ }_{2}^{-}$or $\mathrm{NO}$ production. Second, oral intake of $\mathrm{NO}_{2}$ and $\mathrm{NO}_{3}$ was not restricted in the overall population although some authors have indicated that dietary nitrates are eliminated from the blood by urinary excretion after approximately 12 to $16 \mathrm{~h}$, and therefore measurement of NOx in blood collected after an overnight fast could reliably reflect endogenous NO production [48]. Third, since the study was performed in a small population, further studies in larger samples are required to confirm the current results.

In conclusion, this study demonstrates for the first time that the production of $\bullet \mathrm{O}_{2}{ }^{-}$by NADPH oxidase is increased in PMA-stimulated mononuclear cells from hypertensive patients. Furthermore, our results show an association between exaggerated phagocytic NADPH oxidase-dependent $\bullet \mathrm{O}_{2}{ }^{-}$production and diminished NO generation in these patients. Thus, it is tempting to speculate that phagocytic NADPH oxidase might be involved in diminished $\mathrm{NO}$ availability observed in essential hypertension.

\section{Acknowledgements}

We thank Ana Montoya and Raquel Ros for their technical work.

\section{References}

1 Kojda G, Harrison D. Interactions between NO and reactive oxygen species: pathophysiological importance in atherosclerosis, hypertension, diabetes and heart failure. Cardiovasc Res 1999; 43:562-571.

2 Cai H, Harrison DG. Endothelial dysfunction in cardiovascular diseases: the role of oxidant stress. Circ Res 2000; 87:840-844.

3 Griendling KK, Sorescu D, Ushio-Fukai M. NAD(P)H oxidase: role in cardiovascular biology and disease. Circ Res 2000; 86:494-501.

4 Zalba G, San José G, Moreno MU, Fortuño MA, Fortuño A, Beaumont FJ, et al. Oxidative stress in arterial hypertension: role of $N A D(P) H$ oxidase. Hypertension 2001; 38:1395-1399.

5 Rajagopalan S, Kurz S, Münzel T, Tarpey M, Freeman BA, Griendling KK, et al. Angiotensin II-mediated hypertension in the rat increases vascular superoxide production via membrane NADH/NADPH oxidase activation. Contribution to alterations of vasomotor tone. J Clin Invest 1996; 97:1916-1923 
6 Zalba G, Beaumont FJ, San José G, Fortuño A, Fortuño MA, Etayo JC, et al. Vascular NADH/NADPH oxidase is involved in enhanced superoxide production in spontaneously hypertensive rats. Hypertension 2000; 35:1055-1061.

7 Beswick RA, Dorrance AM, Leite R, Webb RC. NADH/NADPH oxidase and enhanced superoxide production in the mineralocorticoid hypertensive rat. Hypertension 2001; 38:1107-1111.

8 Touyz RM, Schiffrin EL. Increased generation of superoxide by angiotensin II in smooth muscle cells from resistance arteries of hypertensive patients: role of phospholipase D-dependent NAD(P)H oxidase-sensitive pathways. J Hypertens 2001; 19:1245-1254.

9 Babior BM. NADPH oxidase: an update. Blood 1999; 93:1464-1476.

10 Jones RD, Hancock JT, Morice AH. NADPH oxidase: a universal oxygen sensor? Free Radic Biol Med 2000; 29:416-424.

11 Kumar KV, Das UN. Are free radicals involved in the pathobiology of human essential hypertension? Free Radic Res Commun 1993; 19: $55-66$.

12 Mehta JL, Lopez LM, Chen L, Cox OE. Alterations in nitric oxide synthase activity, superoxide anion generation, and platelet aggregation in systemic hypertension, and effects of celiprolol. Am J Cardiol 1994; 74:901-905.

13 Kristal B, Shurtz-Swirski R, Chezar J, Manaster J, Levy R, Shapiro G, et al. Participation of peripheral polymorphonuclear leukocytes in the oxidative stress and inflammation in patients with essential hypertension. Am J Hypertens 1998; 11:921-928.

14 Kopprasch S, Graessler J, Seibt R, Naumann HJ, Scheuch K, Henbge R, et al. Leukocyte responsiveness to substances that activate the respiratory burst is not altered in borderline and essential hypertension. $J$ Hum Hypertens 1996; 10:69-76.

15 Seifert R, Hilgenstock G, Fassbender M, Distler A. Regulation of the superoxide-forming NADPH oxidase of human neutrophils is not altered in essential hypertension. J Hypertens 1991; 9:147-153.

16 Clozel M, Kuhn H, Hefti F, Baumgartner HR. Endothelial dysfunction and subendothelial monocyte macrophages in hypertension. Effect of angiotensin converting enzyme inhibition. Hypertension 1991; 18:132-141.

17 Rodríguez-Iturbe B, Quiroz Y, Nava M, Bonet L, Chávez M, HerreraAcosta J, et al. Reduction of renal immune cell infiltration results in blood pressure control in genetically hypertensive rats. Am J Physiol Renal Physiol 2002; 282:F191-F201.

18 Hilgers KF. Monocytes/macrophages in hypertension. J Hypertens 2002; 20:593-596.

192003 European Society of Hypertension-European Society of Cardiology guidelines for the management of arterial hypertension. $J$ Hypertens 2003; 21:1011-1053.

20 Stolk J, Hiltermann TJ, Dijkman JH, Verhoeven AJ. Characteristics of the inhibition of NADPH oxidase activation in neutrophils by apocynin, a methoxy-substituted catechol. Am J Respir Cell Mol Biol 1994; 11: 95-102.

21 Muijsers RBR, van Den Worm E, Folkerts G, Beukelman CJ, Koster AS, Postma DS, et al. Apocynin inhibits peroxynitrite formation by murine macrophages. Br J Pharmacol 2000; 130:932-936.

22 Tarpey MM, Fridovich I. Methods of detection of vascular reactive species: nitric oxide, superoxide, hydrogen peroxide, and peroxynitrite. Circ Res 2001; 89:224-236.

23 Dörffel Y, Lätsch C, Stuhlmüller B, Schreiber S, Scholze S, Burmester GR, et al. Preactivated peripheral blood monocytes in patients with essential hypertension. Hypertension 1999; 34:113-117.

24 Chen NG, Abbasi F, Lamendola C, McLaughlin T, Cooke JP, Tsao PS, et al. Mononuclear cell adherence to cultured endothelium is enhanced by hypertension and insulin resistance in healthy nondiabetic volunteers. Circulation 1999; 100:940-943.

25 Dörffel Y, Franz S, Prub A, Neumann G, Rohde W, Burmester GR, et al. Preactivated monocytes from hypertensive patients as a factor for atherosclerosis? Atherosclerosis 2001; 157:151-160

26 Lassègue $B$, Clempus RE. Vascular NAD(P)H oxidases: specific features, expression, and regulation. Am J Physiol Regul Integr Comp Physiol 2003; 285:R277-297.

27 Schiffrin EL, Touyz RM. Inflammation and vascular hypertrophy induced by angiotensin II: role of NADPH oxidase-derived reactive oxygen species independently of blood pressure elevation? Arterioscler Thromb Vasc Biol 2003; 23:707-709.

28 Li L, Fink GD, Watts SW, Northcott CA, Galligan JJ, Pagano PJ, et al. Endothelin-1 increases vascular superoxide via endothelin(A)-NADPH oxidase pathway in low-renin hypertension. Circulation 2003; 107: 1053-1058.

29 Liu J, Yang F, Yang XP, Jankowski M, Pagano PJ. NAD(P)H oxidase mediates angiotensin II-induced vascular macrophage infiltration and medial hypertrophy. Arterioscler Thromb Vasc Biol 2003; 23:776-782.

30 Ungvari Z, Csiszar A, Huang A, Kaminski PM, Wolin MS, Koller A. High pressure induces superoxide production in isolated arteries via protein kinase $\mathrm{C}$-dependent activation of $\mathrm{NAD}(\mathrm{P}) \mathrm{H}$ oxidase. Circulation 2003 108:1253-1258.

31 Zalba G, San José G, Beaumont FJ, Fortuño MA, Fortuño A, Díez J. Polymorphisms and promoter overactivity of the p22phox gene in vascular smooth muscle cells from spontaneously hypertensive rats. Circ Res 2001; 88:217-222.

32 Moreno MU, Fortuño A, San José G, Ros R, Olivan S, Montoya A, et al. Functional effect of a new polymorphism in the $N A D(P) H$ oxidase $p 22^{\text {phox }}$ gene in essential hypertension. J Hypertens 2003; 21:P1.269.

33 Moreno MU, San José G, Orbe J, Páramo JA, Beloqui O, Díez J, et al. Preliminary characterisation of the promoter of the human $\mathrm{p} 22^{\text {phox }}$ gene: identification of a new polymorphism associated with hypertension. FEBS Lett 2003; 542:27-31.

34 Berkow RL, Dodson RW. Tyrosine-specific protein phosphorylation during activation of human neutrophils. Blood 1990; 75:2445-2452.

35 Lee VM, Quinn PA, Jennings SC, Ng LL. NADPH oxidase activity in preeclampsia with immortalized lymphoblasts used as models. Hypertension 2003; 41:925-931.

36 Touyz RM, Yao G, Schiffrin EL. c-Src induces phosphorylation and translocation of p47phox: role in superoxide generation by angiotensin II in human vascular smooth muscle Cells. Arterioscler Thromb Vasc Biol 2003; 23:981-987.

37 Mollnau H, Wendt M, Szocs K, Lassegue B, Schulz E, Oelze M, et al. Effects of angiotensin II infusion on the expression and function of $\mathrm{NAD}(\mathrm{P}) \mathrm{H}$ oxidase and components of nitric oxide/cGMP signaling. Circ Res 2002; 90:E58-65.

38 Hua H, Munk S, Goldberg H, Fantus IG, Whiteside Cl. High glucosesuppressed endothelin-1 $\mathrm{Ca}^{2+}$ signaling via NADPH oxidase and diacylglycerol-sensitive protein kinase $\mathrm{C}$ isozymes in mesangial cells. J Biol Chem 2003; 278:33951-33962.

39 Lyamina NP, Dolotovskaya PV, Lyamina SV, Malyshev IY, Manukhina EB Nitric oxide production and intensity of free radical processes in young men with high normal and hypertensive blood pressure. Med Sci Monit 2003; 9:CR304-310.

40 Túri S, Friedman A, Bereczki C, Papp F, Kovàcs J, Karg E, et al. Oxidative stress in juvenile essential hypertension. J Hypertens 2003; 21: $145-152$.

41 Baylis C, Vallance P. Measurement of nitrite and nitrate levels in plasma and urine-what does this measure tell us about the activity of the endogenous nitric oxide system? Curr Opin Nephrol Hypertens 1998; 7:59-62.

42 Dusting GJ. Nitric oxide in cardiovascular disorders. J Vasc Res 1995; 32:143-161.

43 Vasquez-Vivar J, Kalyanaraman B, Martasek P, Hogg N, Masters BS, Karoui $\mathrm{H}$, et al. Superoxide generation by endothelial nitric oxide synthase: the influence of cofactors. Proc Natl Acad Sci USA 1998; 95:9220-9225

44 Laursen JB, Somers M, Kurz S, McCann L, Warnholtz A, Freeman BA et al. Endothelial regulation of vasomotion in apoE-deficient mice: implications for interactions between peroxynitrite and tetrahydrobiopterin. Circulation 2001; 103:1282-1288.

45 Landmesser U, Dikalov S, Price SR, McCann L, Fukai T, Holland SM, et al. Oxidation of tetrahydrobiopterin leads to uncoupling of endothelial cell nitric oxide synthase in hypertension. J Clin Invest 2003; 111 1201-1209.

46 Mollnau H, Schulz E, Daiber A, Baldus S, Oelze M, August M, et al. Nebivolol prevents vascular NOS III uncoupling in experimental hyperlipidemia and inhibits NADPH oxidase activity in inflammatory cells. Arterioscler Thromb Vasc Biol 2003; 23:615-621.

47 Pettit Al, Wong RKM, Lee V, Jennings S, Quinn PA, Ng LL. Increased free radical production in hypertension due to increased expression of the NADPH oxidase subunit p22phox in lymphoblast cell lines. $J$ Hypertens 2002; 20:677-683

48 Rosselli M, Imthurn B, Keller PJ, Jackson EK, Dubey RK. Circulating nitric oxide (nitrite/nitrate) levels in postmenopausal women substituted with 17 beta-estradiol and norethisterone acetate. A two-year follow-up study. Hypertension 1995; 25:848-853. 